\title{
BERPIKIR KRITIS SISWA DALAM PEMBELAJARAN BERBASIS MASALAH BERBANTUAN KUNCI DETERMINASI
}

\author{
Yusi Ardiyanti \\ Program Studi Pendidikan Matematika, \\ Universitas Singaperbangsa Karawang, Indonesia \\ E-mail: yusi.unsika@gmail.com
}

\begin{abstract}
Abstrak
Masalah pokok yang di analisis dalam penelitian ini adalah Pembelajaran Berbasis Masalah (PBM) berbantuan kunci determinasi dapat meningkatkan keterampilan berpikir kritis siswa SMA, metode yang dilakukan dalam penelitian ini adalah Penelitian Tindakan Kelas (PTK) yang dilakukan sebanyak dua siklus dengan masing-masing siklus terdapat dua pertemuan. Dari PTK tersebut di dapat hasil yang menunjukan bahwa terdapat peningkatan rata-rata berpikir kritis yaitu dari 62,89 (siklus I) menjadi 73,42 (siklus II), begitupun dengan setiap indikator pada berpikir kritis terjadi kenaikan, yaitu: indikator memberikan penjelasan dasar mengalami peningkatan sebesar 0,06 (kategori rendah), indikator membangunketerampilan dasar mengalami peningkatan sebesar 0,9 (kategori tinggi) dan indikator menyimpulkan mengalami peningkatan sebesar 0,4 (kategori sedang). Peningkatan ini di hitung berdasarkan rumus gain. Jadi dapat disimpulkan bahwa pembelajaran berbasis masalah berbantuan kunci determinasi dapat meningkatkan berpikir kritis siswa SMA.
\end{abstract}

Kata kunci: Pembelajaran berbasis masalah, kunci determinasi, berpikir kritis

\begin{abstract}
The main problem in the analysis in this study is the Problem Based Learning (PBM) aided determination key can enhance critical thinking skills of high school students, the method used in this research is the Classroom Action Research (CAR) conducted by two cycles with each cycle there are two meetings. Of PTK is in the can results show that there is an average increase learning outcomes, namely from 62.89 (first cycle) to 73.42 (second cycle), as well as with each indicator in an increase in critical thinking, namely: the indicator gives a basic explanation an increase of 0.06 (low category), basic membangunketerampilan indicator increased by 0.9 (high category) and concluded indicator increased by 0.4 (medium category). This increase is calculated based on the formula gain. So it can be concluded that the key problem-based learning aided determination can improve critical thinking high school students.
\end{abstract}

Keywords : Problem-based learning (PBM), a key determination, think critically

\section{PENDAHULUAN}

Penguasaan ilmu-ilmu dasar (basic science) pada siswa, khususnya IImu Pengetahuan Alam (IPA) merupakan fondasi bagi perkembangan ilmu pengetahuan dan teknologi pada masa yang akan datang. Namun di sisi lain, mata pelajaran IPA sering dianggap sebagai materi sulit dan menjadi hal yang menakutkan bagi sebagian siswa, bahkan sebagian guru. Pembelajaran siswa di sekolah kemudian sekedar menjadi kewajiban menjalankan kurikulum, kehilangan daya tariknya dan lepas relevansinya dengan dunia nyata yang seharusnya menjadi objek ilmu pengetahuan tersebut (Depdiknas, 2003). 
Berpikir kritis merupakan salah satu keterampilan berpikir tingkat tinggi yang harus ditanamkan pada cara berpikir siswa. Seperti halnya yang di katakan Costa (dalam Liliasari, 2005) bahwa berpikir dasar meliputi menghapal, mengelompokkan, membandingkan, membayangkan, menggeneralisasi mengevaluasi, menganalisis, mensintensis, mendedukasi, dan menyimpulkan. Untuk menanamkan cara berpikir kritis ini berbagai cara dapat dilakukan salah satunya yaitu dengan menggunakan Pembelajaran Berbasis Masalah (PBM). Duch (2001) menyatakan bahwa Pembelajaran Berbasis Masalah (PBM) merupakan metode pendidikan yang mendorong siswa mengenal cara belajar dan bekerja sama dalam kelompok untuk mencari penyelesaian masalah-masalah dalam dunia nyata.

Dalam PBM siswa diperkenalkan pada konsep melalui masalah yang terjadi di lingkungannya. Dengan pembelajaran ini siswa dapat tertantang untuk memecahkan masalah dengan mencari berbagai penjelasan yang dapat mengungkap dan menyelesaikan masalah tersebut. Dalam usaha-usaha untuk menjelaskan fenomena tersebut siswa diberi banyak kesempatan untuk meningkatkan keterampilan berpikirnya. Kemampuan mencari, mengumpulkan, mengidentifikasi dan memilih informasi yang tepat untuk dapat menjelaskan fenomena yang terjadi akan terasah. Dengan demikian diharapkan keterampilan berpikir siswa dapat ditingkatkan melalui pembelajaran dengan PBM.

Ketertarikan siswa dengan model pembelajaran ini juga bisa disebabkan oleh otentitas materi yang disampaikan sehingga bermakna bagi siswa itu sendiri. Ibrahim dan Nur (2000) menyampaikan bahwa model PBM merupakan model belajar yang mengorganisasikan pembelajaran di sekitar pertanyaan dan masalah, melalui pengajuan situasi kehidupan nyata yang autentik, yang mendorong siswa untuk melakukan penyelidikan dan inkuiri, dengan menghindari jawaban sederhana, serta memungkinkan adanya berbagai macam solusi dari situasi tersebut.

$\begin{array}{ccr}\text { Hal tersebut sejalan } & \text { dengan } \\ \text { pendapatnya } & \text { Arends } & \text { (2004) } \\ \text { yang }\end{array}$

menyatakan bahwa dengan belajar berbasis masalah siswa akan mampu membangun pikiran mereka dan keterampilan pemecahan masalah, belajar berperan sebagai orang dewasa, dan menjadi pebelajar yang mandiri. Lebih lanjut dikatakan bahwa model pembelajaran ini juga dapat merangsang berpikir tingkat tinggi siswa dalam situasi berorientasi masalah, termasuk didalamnya belajar bagaimana belajar. PBM menuntut siswa untuk dapat menjelaskan fenomena yang terjadi dengan berbagai cara (alat atau bahan), sehingga alat bantu yang paling relevan dan bisa digunakan pada pembelajaran biologi adalah dengan menggunakan bantuan kunci determinasi, karena Suroso Adi (1991) menyatakan bahwa kunci determinasi adalah alat bantu yang paling memudahkan siswa untuk mengidentifikasi hewan atau tumbuhan berdasarkan atas persamaan ciri morfologi. Berdasarkan hal itu maka materi yang paling relevan dalam penelitian ini adalah keanekaragaman hayati dalam hal klasifikasi makhluk hidup dengan materi invertebrata dan vertebrata.

$$
\text { Untuk mencapai tujuan }
$$

pembelajaran guru harus menerapkan model pembelajaran yang dapat memotivasi siswa dan mengarahkan siswa untuk meningkatkan kemampuan berpikir kritis mereka, agar dapat memecahkan masalah dalam pembelajaran yang diberikan oleh guru. Kemampuan berpikir kritis siswa dapat ditingkatkan dengan menerapkan pembelajaran yang berpusat pada siswa (Aryana, 2009). Sedangkan Beyer (dalam Filsaime, Dennis K, 2008) menyatakan bahwa berpikir kritis adalah membuat suatu penilaian-penilaian yang masuk akal. Beyer memandang berpikir kritis digunakan sebagai kriteria untuk menilai kualitas sesuatu, dari kegiatan yang paling sederhana seperti kegiatan normal seharihari. Kemuadian menurut Screven (2008) memandang berpikir kritis sebagai proses disiplin cerdas dari konseptualisasi, penerapan, analisis, sintesis dan evaluasi aktif dan berketrampilan yang dikumpulkan dari, atau dihasilkan oleh, observasi, pengalaman, refleksi, penalaran atau komunikasi sebagai sebagai sebuah penuntun menuju kepercayaan dan aksi. 
Uraian pendapat di atas dapat disimpulkan bahwa berpikir kritis adalah suatu proses kemampuan untuk memecahkan masalah berdasarkan pertimbangan yang baik serta pengalaman-pengalaman yang sesuai dengan fakta yang ada. Kemampuan berpikir kritis ini merupakan proses berpikir untuk memecahkan masalah dalam proses pembelajaran, sehingga dapat diambil suatu keputusan yang terbaik yang dapat dilaksanakan.

Kemampuan berpikir kritis ini dapat dilatihkan di sekolah manapun melalui suatu proses belajar. Suatu proses pembelajaran dapat tercapai serta dapat meningkatkan kemampuan berpikir kritis dalam memecahkan masalah dalam proses belajar, yang pada intinya berpusat pada siswa. Menurut Garrison (dalam Filsaisme Denis K, 2008) ada lima tahap berpikir kritis yaitu satu mendefinisikan masalah dengan jelas, dua mengeksplorasi masalahmasalah tiga solusi-solusi yang mungkin, empat mengevaluasi penerapannya dan lima mengintegrasikan pemahaman ini dengan pengetahuan yang ada. Sedangkan Watson dan Glaser (dalam Filsaisme Denis K, 2008) memandang berpikir kritis sebagai sebuah gabungan sikap, pengetahuan dan kecakapan. Moor dan Parker (dalam Aryana, 2009) mendefinisikan berpikir kritis sebagai pertimbangan yang cermat dalam memberikan keputusan untuk menerima atau menolak suatu pernyataan yang bersifat benar atau salah. Sedangkan Roland (dalam Sudiarta, 2008) menyatakan bahwa kemampuan berpikir kritis melibatkan kemampuan untuk membuat alasan yang masuk akal dalam situasi yang komplesk, seperti misalnya yang ditemukan dalam masyarakat yang modern dan cepat berubah. Pengertian ini menekankan pentingnya "mengetahui" dari pada mengetahui apa.

Berpikir merupakan suatu proses kognisi, suatu aktifitas mental untuk memperoleh suatu pengetahuan. Berdasarkan prosesnya berpikir dikelompokan kedalam berpikir dasar (berpikir rasional) dan berpikir kompleks (berpikir tingkat tinggi). Berpikir dasar meliputi menghapal, membayangkan, mengelompokan, menggeneralisasi, membandingkan, mengevaluasi, menganalisis, mensintesis, mendeduksi dan menyimpulkan. Sedangkan proses berpikir kompleks terdiri dari empat macam yaitu pemecahan masalah, pengambilan keputusan, berpikir kritis dan berpikir kreatif (Costa dalam Liliasari, 2005).

Peneliti pendidikan dan pengembang program (Costa, 1985; Keating, 1988) menyebutkan ada 4 elemen dalam berpikir kritis diantaranya pertama pengetahuan, kedua pengetahuan prosedural, ketiga kemampuan untuk memonitor, menggunakan dan mengontrol keterampilan berpikir (metacognition) dan keempat kemampuan untuk menggunakan keterampilan berpikir dan pengetahuannya.

Sejalan dengan itu Definisi berpikir kritis menurut Beyer (1985) : Berpikir kritis adalah kemampuan pertama menentukan kredibilitas suatu sumber, kedua membedakan antara yang relevan dari yang tidak relevan, ketiga membedakan fakta dari penilaian, keempat mengidentifikasi dan mengevaluasi asumsi yang tidak terucapkan, kelima mengidentifikasi bias yang ada, keenam mengidentifikasi sudut pandang, dan ketujuh mengevaluasi bukti yang ditawarkan untuk mendukung pengakuan. Namun berpikir kritis menurut Mustaji (2012) adalah berpikir secara beralasan dan reflektif dengan menekankan pembuatan keputusan tentang apa yang harus dipercayai atau dilakukan. Berikut adalah contoh-contoh kemampuan berpikir kritis, misalnya satu membanding dan membedakan, dua membuat kategori, tiga meneliti bagian-bagian kecil dan keseluruhan, empat menerangkan sebab, lima membuat sekuen /urutan, enam menentukan sumber yang dipercayai, dan tujuh membuat ramalan.

Ahli lain pun mendefinisikan tentang berfikir kritis, diantaranya, yaitu: Walker (2006) yang menyebutkan bahwa berpikir kritis adalah suatu proses intelektual dalam pembuatan konsep, mengaplikasikan, menganalisis, mensintesis, dan atau mengevaluasi berbagai informasi yang didapat dari hasil observasi, pengalaman, refleksi, di mana hasil proses ini diguanakan sebagai dasar saat mengambil tindakan. Atau menurut Hassoubah (2007) menyatakan bahwa berpikir kritis adalah kemampuan memberi alasan secara 
terorganisasi dan mengevaluasi kualitas suatu alasan secara sistematis. Jadi berpikir kritis adalah sebuah keterampilan yang harus di miliki oleh siswa untuk mencapai kompetensi yang diharapkan. Pada dasarnya keterampilan berpikir kritis (abilities) menurut Ennis (Costa, 1985:54) dikembangkan menjadi indikator-indikator keterampilan berpikir kritis yang terdiri dari lima kelompok besar yaitu: pertama, Memberikan penjelasan sederhana (elementary clarification); kedua Membangun keterampilan dasar (basicsupport); ketiga menyimpulkan (interference); keempat Memberikan penjelasan lebih lanjut (advanced clarification); kelima mengatur strategi dan taktik (strategy and tactics).Untuk menanamkan cara berpikir kritis ini berbagai cara dapat dilakukan salah satunya yaitu dengan menggunakan Pembelajaran Berbasis Masalah (PBM).

Pembelajaran Berbasis Masalah (PBM) sendiri merupakan pembelajaran yang berfokus pada kegiatan memecahkan masalah, dan masalah yang dihadapi merupakan masalah yang tidak rutin dihadapi siswa sehingga menantang siswa untuk berpikir dan melakukan pemikiran yang tepat. Pada proses pembelajaran berbasis masalah, pengetahuan siswa dibangun melalui serangkaian kegiatan penyelesaian permasalahan yang dihadapi siswa. Mereka menggali konsep dan prinsip melalui penelaahan terhadap permasalahan yang harus dilakukan secara tepat dengan pengetahuan awal yang telah mereka miliki.

Pembelajaran berbasis masalah (PBM) merupakan salah satu model pembelajaran inovatif yang dapat memberikan kondisi belajar aktif kepada siswa dan dihadapkan pada permasalahan dunia nyata. Hal ini, sejalan dengan pendapat Ibrahim dan Nur (Rusman, 2010) yang mengemukakan pembelajaran berbasis masalah merupakan salah satu pendekatan pembelajaran yang digunakan untuk merangsang berpikir tingkat tinggi siswa dalam situasi yang berorientasi pada masalah dunia nyata, termasuk di dalamnya belajar bagaimana belajar. Sedangkan menurut Boud dan Feletti (Rusman, 2010) Pembelajaran Berbasis Masalah adalah inovasi yang paling signifikan dalam pendidikan.

Duch

$$
\text { (2001) }
$$

menyatakan

pembelajaran berbasis masalah merupakan metode pendidikan yang mendorong siswa mengenal cara belajar dan bekerja sama dalam kelompok untuk mencari penyelesaian masalah-masalah dalam dunia nyata. Simulasi masalah yang digunakan untuk mengaktifkan keingintahuan siswa sebelum mulai mempelajari suatu subyek.

Sejalan dengan pendapat tersebut, Tan (Rusman, 2010) mengemukakan, pembelajaran berbasis masalah merupakan inovasi dalam pembelajaran karena dalam pembelajaran berbasis masalah kemampuan berpikir peserta didik betulbetul dioptimalisasikan melalui proses kerja kelompok atau tim yang sistematis, sehingga peserta didik dapat memberdayakan, mengasah, menguji dan mengembangkan kemampuan berpikirnya secara berkesinambungan. Dalam hal ini Trianto (2007) juga menyatakan bahwa pembelajaran berbasis masalah adalah suatu model pembelajaran yang didasarkan pada banyaknya permasalahan yang membutuhkan penyelidikan autentik yaitu penyelidikan yang membutuhkan penyelesaian nyata dari permasalahanpermasalahan yang nyata. Jadi pembelajaran berbasis masalah (PBM) sendiri merupakan pembelajaran yang berfokus pada kegiatan memecahkan masalah, dan masalah yang dihadapi merupakan masalah yang tidak rutin dihadapi siswa sehingga menantang siswa untuk berpikir dan melakukan pemikiran yang tepat. Dalam membuat tugas pembelajaran berbasis masalah ada empat langkah dasar yang perlu diperhatikan (Zarkon, 2001) yaitu: pertama penyajian masalah yang ada, kedua membangun dasar pengetahuan siswa, ketiga Mendukung siswa untuk memecahkan masalah, dan keempat solusi yang teruji dan mampu direvisi

Dalam hal penyajian masalah, seharusnya dapat dikenali dan dimengerti. Ini merupakan motivasi bagi siswa untuk memecahkan masalah yang distimulasi oleh masalah yang relevan dengan siswa. Pengetahuan, kemampuan dan 
pengalaman yang dibutuhkan untuk memecahkan masalah perlu dibangun dalam tahap membangun dasar pengetahuan siswa. Sumber informasi yang bervariasi, penggunaan simulasi dan multimedia dapat berguna untuk membangun pengetahuan dan kemampuan prasyarat.

Langkah mendukung siswa dalam pemecahan masalah dapat membantu waktu dan sumber yang digunakan siswa. Guru dapat bertindak sebagai fasilitator dan nara sumber. Guru pun harus membuat rencana waktu yang dibutuhkan dan perlengkapan yang pantas untuk dapat memecahkan masalah. Pengujian dan revisi penyelesaian merupakan suatu aktivitas yang perlu dilakukan dalam pembelajaran berbasis masalah. Aktivitas yang akan dilakukan harus direncanakan untuk mendapatkan hasil yang baik dan siswa mendapatkan feedback untuk solusi yang diberikan, untuk menemukan contoh baru bagaimana masalah dapat dipecahkan dan menemukan informasi baru yang dapat merevisi solusi masalah yang di hadapi. Seperti halnya tahap pembelajaran menurut Ibrahim (2000) dapat dilihat pada Tabel 1.

Tabel 1. Lima Tahap Pembelajaran Berbasis Masalah (Ibrahim, 2000)

\begin{tabular}{|c|c|}
\hline Tahapan & Kegiatan Guru \\
\hline $\begin{array}{l}\text { Tahap } 1 \\
\text { Mengorientasi siswa pada }\end{array}$ & $\begin{array}{l}\text { dan logistlk yang } \\
\text { jat dalam aktivitas }\end{array}$ \\
\hline $2 . \quad . \quad 2+1$ & $\begin{array}{l}\text { antu siswa mendefinisikan dan mengorgani } \\
\text { belajar yang berhubungan dengan mas } \\
\text { ut }\end{array}$ \\
\hline $\begin{array}{l}\text { abing penyelidikan } \\
\text { kelompok }\end{array}$ & $\begin{array}{l}\text { Mendorong siswa untuk mengumpulkan informasi } \\
\text { yang sesuai, melaksanakan eksperimen, untuk } \\
\text { mendapatkan penjelasan dan pemecahan masalah. }\end{array}$ \\
\hline $\begin{array}{l}\text { Tahap } 4 \\
\text { Mengembangkan dan menyajikan } \\
\text { hasil karya }\end{array}$ & $\begin{array}{l}\text { Membantu siswa dalam merencanakan dan } \\
\text { menyiapkan karya yang sesuai }\end{array}$ \\
\hline $\begin{array}{l}\text { Tahap } 5 \\
\text { Menganalisa dan mengeval } \\
\text { proses pemecahan masalah }\end{array}$ & $\begin{array}{l}\text { Membantu siswa untuk melakukan refleksi atau } \\
\text { evaluasi terhadap penyelidikan mereka dan proses - } \\
\text { proses yang mereka gunakan }\end{array}$ \\
\hline
\end{tabular}

Berdasarkan pengertian-pengertian pada Tabel 1, untuk penyelidikan autentik, siswa memerlukan alat bantu yang relevan yang di sesuaikan dengan permasalahan pada materi yang sedang di bahas. Suroso Adi (1991) menyatakan bahwa dari sekian alat bantu yang dapat digunakan untuk membantu siswa mengamati variasi-variasi struktural pada hewan-hewan tersebut, membina kemampuan menafsirkan perbedaan yang tampak antar struktur yang khas ditunjukan hewan tertentu dibandingkan dengan struktur umum berlaku bagi kelompoknya, kunci determinasi dianggap lebih mudah dari alat bantu lainnya.

Sejalan dengan itu maka kunci determinasi dengan sebutan kunci analitik merupakan suatu alat yang dapat digunakan untuk mengidentifikasi segala macam benda hidup (Boen. S. Oemarjati, 1990) karena kunci determinasi merupakan suatu cara untuk menentukan kedudukan hewan atau tumbuhan dalam klasifikasinya.

Saran-saran dalam penggunaan kunci determinasi: pertama, kumpulkan informasi sebanyak mungkin tentang ciri tumbuhan yang akan dideterminasi (kalau ada lengkap vegetatif dan generatif); kedua, pilih kunci yang sesuai dengan materi tumbuhan dan daerah geografi di mana tumbuhan tersebut diperoleh; ketiga, baca pengantar kunci tersebut dan semua singkatan atau hal-hal lain yang lebih rinci; keempat, perhatikan pilihan yang ada secara hati-hati; kelima, hendaknya semua istilah yang ada dipahami artinya. Gunakan glossary atau kamus; keenam, bila 
spesimen tersebut tidak cocok dengan semua kunci dan semua pilihan layaknya tidak kena, mungkin terjadi kesalahan, ulangi ke belakang; ketujuh, apabila kedua pilihannya mugkin, coba ikuti keduanya; kedelapan, konfirmasikan pilihan tersebut dengan membaca deskripsinya; dan kesembilan, spesimen yang berhasil dideterminasi sebaiknya diverifikasi dengan ilustrasi atau specimen herbarium yang ada.

Penggunaan kunci determinasi pertama kali diperkenalkan oleh Carolus Linnaeus. Namun, sebenarnya Lammarck (1778) juga pernah menggunakan kunci modern untuk identifikasi. Salah satu kunci identifikasi ada yang disusun dengan menggunakan ciri-ciri taksonomi yang saling berlawanan. Tiap langkah dalam kunci tersebut terdiri atas dua alternatif (dua ciri yang saling berlawanan) sehingga disebut kunci determinasi. Cara menggunakan kunci determinasi antara lain sebagai berikut: satu Bacalah dengan teliti kunci determinasi mulai dari permulaan, yaitu nomor $1 \mathrm{a}$, dua Cocokkan ciri-ciri tersebut pada kunci determinasi dengan ciri yang terdapat pada makhluk hidup yang diamati, tiga Jika ciri-ciri pada kunci tidak sesuai dengan ciri makhluk hidup yang diamati, maka harus beralih pada pernyataan yang ada di bawahnya dengan nomor yang sesuai. Misalnya, pernyataan 1a tidak sesuai, beralihlah ke pernyataan $1 b$, empat Jika ciri-ciri yang terdapat pada kunci determinasi sesuai dengan ciri yang dimiliki organisme yang diamati, catatlah nomornya. Lanjutkan pembacaan kunci pada nomor yang sesuai dengan nomor yang tertulis di belakang setiap pernyataan pada kunci, lima Jika salah satu pernyataan ada yang cocok atau sesuai dengan makhluk hidup yang diamati, alternatif lainnya akan gugur. Sebagai contoh, kunci determinasi memuat pilihan: a. Tumbuhan berupa herba, atau b. Tumbuhan berkayu, enam Jika yang dipilih adalah 1a (tumbuhan berupa herba), pilihan 1b gugur, dan tujuh Begitu seterusnya hingga diperoleh nama famili, ordo, kelas, dan divisio atau filum dari makhluk hidup yang diamati. Pada umumnya, buku penuntun identifikasi makhluk hidup dilengkapi dengan kunci determinasi dan hanya berlaku setempat (lokal).

\section{METODE}

Jenis penelitian ini adalah penelitian tindakan kelas (PTK) yang bertujuan untuk meningkatkan kualitas pelaksanaan pembelajaran di kelas. Menurut Aqib (2006) PTK adalah penelitian yang dilakukan oleh guru dimana guru tersebut mengajar dengan penekanan pada penyempurnaan atau peningkatan dan proaksis pembelajaran. Penelitian tindakan kelas ini dilakukan di SMA Negeri 2 Cikampek Kabupaten Karawang. Pada tahap penentuan subjek, peneliti berkonsultasi dengan wakasek kurikulum untuk meminta siswa di kelas $X$ sebagai subjek penelitian, maka berdasarkan hal itu yang menjadi subjek penelitiannya adalah siswa kelas X8 yang berjumlah 38 orang.

Prosedur penelitian yang diterapkan dalam hal ini meliputi tiga tahapan, yaitu antara lain: Tahap Pertama yaitu perencanaan, meliputi analisis materi, pengumpulan pertanyaan produktif untuk disampaikan pada siswa yang berguna mengetahui kemampuan awal siswa, penyampaian materi pelajaran, pembelajaran PBM, latihan soal penggunaan kunci determinasi, pembahasan latihan soal. Tahap Kedua yaitu tahap pelaksanaan yaitu terdiri dari dua siklus, Siklus dengan materi Invertebrata (dua pertemuan) dan Siklus II dengan materi vertebrata (dua pertemuan) dimana setiap siklus di akhiri dengan sebuah evaluasi untuk mengukur tingkat keberhasilan PBM dengan bantuan kunci determinasi untuk berpikir kritis siswa. Dan tahap ketiga yaitu refleksi, dimana perlu adanya pembahasan antara siklus-siklus tersebut untuk dapat menentukan kesimpulan atau hasil dari penelitian.

Instrumen yang digunakan dalam penelitian ini berupa tes tulis yang dilaksanakan pada akhir setiap siklus. Tes akhir ini menggunakan indikator kemampuan berpikir kritis, indikator yang digunakan pada penelitian ini adalah tiga indikator dari lima indikator yang ada menurut Ennis. Alasan peneliti hanya menggunakan tiga indikator adalah karena instrumen ini berdasarkan hasil validasi, yang setelah validasi di dapat instrumen dengan tiga indikator saja, selain itu juga di sesuaikan dengan indikator dan tujuan 
pembelajaran yang digunakan pada saat proses pembelajaran berlangsung, maka di dapat hasil seperti pada Tabel 2.

Data yang dikumpulkan dalam penelitian ini adalah data kuantitatif berupa skor tes keterampilan berpikir kritis yang diambil pada setiap akhir siklus, skor tes akhir pembelajaran tersebut untuk siklus I dan siklus II. Untuk skor keterampilan berpikir kritis, dianalisis secara deskriptif dengan mencari nilai rata-rata tiap butir soal, dan ketuntasan belajar siswa. Kriteria keberhasilan peningkatan kualitas pembelajaran biologi, ditinjau hasil belajar siswa. Kemudian untuk peningkatannya digunakan rumus Gain.

Data tes akhir setiap siklus mengenai keterampilan berpikir kritis siswa untuk materi invertebrata dan vertebrata dianalisis dengan cara mengkonversi nilai rata-rata setiap butir soal pada setiap indikator dan dimasukkan ke pedoman konversi nilai (nilai gain) dan indikatornya. Hal ini, untuk menentukan tingkat kualifikasi keterampilan berpikir kritis siswa untuk materi invertebrata dan vertebrata dan peningkatan hasil belajar siswa dengan menggunakan pembelajaran berbasis masalah dengan bantuan kunci determinasi.

Tabel 2. Indikator Berfikir Kritis yang Digunakan dalam Instrumen

\begin{tabular}{clcc}
\hline No & \multicolumn{1}{c}{ Indikator } & $\begin{array}{c}\text { Jumlah soal } \\
\text { Invertebrata }\end{array}$ & $\begin{array}{c}\text { Jumlah soal } \\
\text { vertebrata }\end{array}$ \\
\hline 1 & Memberikan penjelasan dasar & 6 & 3 \\
2 & Membangun keterampilan dasar & 6 & 3 \\
3 & Menyimpulkan & 1 & 1 \\
4 & Membuat penjelasan lebih lanjut & 0 & 0 \\
5 & Strategi dan taktik & 0 & 0 \\
\hline
\end{tabular}

\section{HASIL DAN PEMBAHASAN}

Pada tahap perencanaan peneliti melakukan langkah-langkah (1) mengkaji materi pokok, mempersiapkan silabus, dan rencana pelaksanaan pembelajaran, dan lembar kegiatan siswa termasuk di dalamnya kunci determinasi, (2) mempersiapkan dan mengkaji format-format evaluasi yang terdiri dari soal tes akhir pembelajaran, mengkaji indikator untuk menentukan keberhasilan tindakan yang dilaksanakan, seperti rubrik penilaian keterampilan berpikir kritis.

Pelaksanaan tindakan pada prinsipnya merupakan realisasi dari suatu tindakan yang sudah direncanakan. Pada siklus I, materi pokok yang dikaji adalah invertebrata yang dilaksanakan untuk dua kali pertemuan (4x45 menit). Sedangkan pada siklus II untuk materi pokok vertebrata yang dilaksanakan untuk dua kali pertemuan (4x 45 menit). Adapun langkah-langkah pelaksanaan tindakan, sebagai berikut: Sebelum pembelajaran dimulai, langkah pertama yang dilaksanakan oleh guru adalah memberikan pertanyaan produktif yang di jawab oleh siswa untuk untuk mengetahui pengetahuan awal siswa terhadap bahan kajian yang akan dibahas. Pembelajaran dilakukan dengan langkahlangkah pembelajaran berbasis masalah, yaitu satu mengorientasi siswa pada masalah, dua mengorganisasi siswa untuk belajar, tiga membimbing penyelidikan individu maupun kelompok, empat mengembangkan dan menyajikan hasil karya, dan lima menganalisis dan mengevaluasi proses pemecahan masalah.

Selama pembelajaran berlangsung, peneliti melakukan observasi terhadap strategi pembelajaran yang diterapkan dan melakukan perekaman terhadap proses belajar mengajar yang berlangsung melalui CCTV yang di sediakan oleh sekolah yang ada di setiap kelas. Variabel yang diamati sesuai dengan objek penelitian. Kemudian tahap akhir yaitu pemberian tes yang dilakukan untuk mengetahui peningkatan rata-rata hasil belajar diakhir setiap siklus dengan menggunakan instrument berfikir kritis.

Berdasarkan observasi dan evaluasi pada siklus I, peneliti mengadakan refleksi untuk melihat seberapa besar keberhasilan 
dan kegagalan dalam penerapan pembelajaran yang dirancang. Refleksi dilakukan terhadap pencapaian keterampilan berpikir kritis siswa dan mencari faktor-faktor penyebab ketidakberhasilan tindakan serta mencari solusi terhadap permasalahan tersebut, serta upaya yang perlu dilakukan untuk meningkatkannya. Analisis melalui CCTV yang dilakukan pada penerapan siklus I dievaluasi dan diinterpretasi penyebabnya untuk selanjutnya digunakan sebagai acuan dalam melakukan pemantapan pada siklus II.

Berdasarkan instrumen yang telah di analisis dan dengan langkah-langkah yang telah di lalui, maka data yang diperoleh dan dianalisis dalam penelitian ini digunakan untuk menjawab masalah penelitian. Nilai rata-rata setiap siklus dan nilai rata-rata untuk setiap indikator berpikir kritis pada setiap siklus dapat dilihat pada Tabel 3.

Tabel 3 Keterampilan Berpikir Kritis Setiap Indikator

\begin{tabular}{clcccc}
\hline No & Indikator Penilaian & $\begin{array}{c}\text { Nilai rata- } \\
\text { rata Siklus I }\end{array}$ & $\begin{array}{c}\text { Nilai rata- } \\
\text { rata Siklus II }\end{array}$ & Gain & Kategori \\
\hline 1 & Memberikan penjelasan dasar & 48,95 & 51,04 & 0,06 & Rendah \\
2 & Membangun keterampilan dasar & 50,69 & 76,38 & 0,9 & Tinggi \\
3 & menyimpulkan & 52,63 & 73,68 & 0,4 & Sedang \\
4 & Membuat penjelasan lebih lanjut & - & - & - & - \\
5 & Strategi dan taktik & - & - & - & - \\
& & 62,89 & 73,42 & 0,03 & Rendah \\
\hline
\end{tabular}

Data pada Tabel 3 menunjukkan adanya peningkatan keterampilan berpikir kritis siswa. Peningkatan tersebut ditunjukkan dengan peningkatan nilai ratarata dari setiap butir soal yang memilki indikator berfikir kritis. Pada Tabel 3 terlihat nilai rata-rata secara keseluruhan untuk siklus I yaitu sebesar 62,89 menjadi 73,42 untuk siklus II, berdasarkan nilai gain nya secara keseluruhan nilai siswa mengalami peningkatan sebesar $(0,03)$ kategori rendah. Namun walau begitu dari data di atas juga dapat diketahui bahwa dari kelima indikator berpikir kritis, yang digunakan pada penelitian ini hanya tiga indikator saja dan semuanya mengalami peningkatan.

Peningkatan tertinggi ada pada indikator membangun keterampilan dasar yaitu dari 50,69 (siklus I) menjadi 76,38 (siklus II) berarti mengalami penngkatan sebesar 0,9 (kategori tinggi), diikuti dengan indikator menyimpulkan berada pada kategori sedang dengan Gain sebesar 0,4 (dari nilai rata-rata 52,63 pada siklus I menjadi 73,68 pada siklus II) dan terakhir untuk indikator memberikan penjelasan ada di kategori rendah yaitu sekitar 0,06 (dari nilai rata-rata 48,95 pada siklus I menjadi 51,04 pada siklus II). Untuk lebih mudah disajikan pada gambar 1 dan gambar 2 .
Grafik 1. Hasil Peningkatan Pembelajaran dari Siklus I dan Siklus II

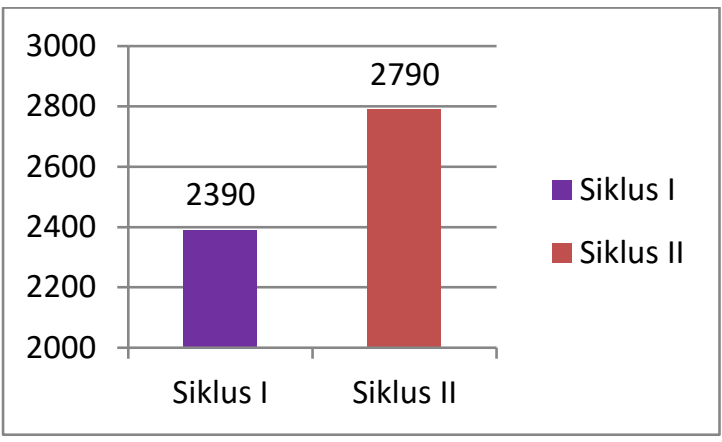

Grafik 2. Peningkatan Hasil Belajar Setiap Indikator Dari Setiap Siklus

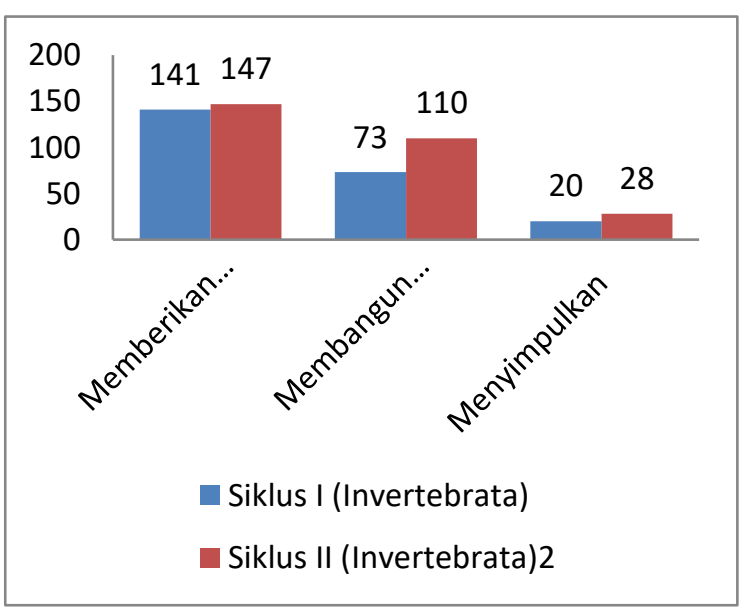


Pada siklus I banyak siswa yang masih kebingungan dengan aturan-aturan atau tahapan pembelajaran ini, ini di sebabkan karena masih rendahnya pengetahuan awal siswa. Rendahnya pengetahuan awal siswa merupakan salah satu faktor yang menentukan keterampilan berpikir kritis siswa, juga dengan banyaknya nama ilmiah yang harus di pahami. Dengan demikian pengetahuan awal merupakan informasi sebagai bahan refleksi bagi guru untuk merencanakan strategi pembelajaran. Hal ini karena salah satu indikator kualitas proses pembelajaran adalah mengaitkan pengetahuan awal yang dimiliki siswa dengan bahan kajian yang akan dibahas (Depdiknas, 2002).

Akibat pengetahuan awal siswa yang masih rendah maka perlu direncanakan pembelajaran yang memberikan pengalaman konkrit kepada siswa. Salah satu diantaranya adalah dengan menerapkan pembelajaran berbasis masalah dengan bantuan kunci determinasi. Masalah yang dipecahkan adalah masalah yang sering ditemukan dalam kehidupan nyata sehari-hari, di berikan panduan gambar sebagai pembelajaran yang kontekstual. Melalui penerapan pembelajaran ini, siswa dapat mengikuti prosedur pembelajaran yang bermakna, dan mengandung langkah-langkah mengamati, melakukan, dan menginterpretasi data hasil pengamatan. Hal ini sesuai dengan yang disebutkan oleh Edgar Dale bahwa pengalaman belajar yang paling tinggi tingkatannya adalah pengalaman belajar konkret. Sedangkan yang paling rendah adalah pengalaman belajar abstrak (Ali, 2000).

Berdasarkan hal itu, maka penerapan pembelajaran berbasis masalah dalam pembelajaran Biologi, secara umum direspon positif oleh siswa. Hal ini terlihat dari kesungguhan dan kehadiran siswa mengikuti pembelajaran. Penerapan pembelajaran berbasis masalah mampu meningkatkan motivasi dan minat siswa untuk belajar lebih baik. Ini sesuai dengan pendapat Jordan E Ayan (2002) yang menyatakan bahwa dalam proses pembelajaran, cara dan gaya baru yang disajikan kepada siswa, pada umumnya menimbulkan rasa ingin tahu siswa. Rasa ingin tahu mendorong seseorang untuk menyelidiki bidang baru atau mencari cara mengerjakan sesuatu dengan lebih baik.

Penerapan model pembelajaran berbasis masalah juga dapat mengoptimalkan pengalaman belajar, seperti pengalaman mengamati, mencatat data, dan melakukan kajian literatur, serta mengkomunikasikan pengetahuan. Keadaan ini mendorong aksi dan refleksi pada siswa, untuk segera tanggap dengan situasi pembelajaran yang baru. Pembelajaran yang melibatkan seluruh indera akan lebih bermakna dibandingkan dengan satu indera saja. Hal ini di tambah lagi dengan adanya bantuan kunci determinasi, sehingga memudahkan siswa untuk mengetahui tingkat kekerabatan sesama hewan.

\section{SIMPULAN DAN SARAN}

Berdasarkan hasil analisis data dan temuan penelitian selama pembelajaran, maka dapat disimpulkan : pertama pembelajaran berbasis masalah dengan bantuan kunci determinasi dapat meningkatkan berpikir kritis siswa; rata-rata peningkatan adalah Siklus I sebesar 62, 89 dan siklus II sebesar 73,42, kedua pembelajaran berbasis masalah dengan bantuan kunci determinasi dapat meningkatkan berpikir kritis siswa untuk indikator memberikan penjelasan dasar; peningkatan berdasarkan gain sebesar 0,06 (kategori rendah), ketiga pembelajaran berbasis masalah dengan bantuan kunci determinasi dapat meningkatkan berpikir kritis siswa untuk indikator membangun keterampilan dasar; peningkatan berdasarkan gain sebesar 0,9 (kategori tinggi), keempat pembelajaran berbasis masalah dengan bantuan kunci determinasi dapat meningkatkan berpikir kritis siswa untuk indikator memberikan menyimpulkan; peningkatan berdasarkan gain sebesar 0,4 (kategori sedang).

\section{DAFTAR PUSTAKA}

Adi. Yudianto. Suroso. (1999). Abstraksi Disertasi Program Studi Pendidikan IImu Pengetahuan Alam. Bandung: UPI Bandung: tidak diterbitkan. 
Arends, R. I. (2004). Learning to Teach (6th Edition). New York: McGraw-Hill

Arikunto, S. (2005). Dasar-dasar Evaluasi Pendidikan. Jakarta. Bumi Aksara.

Aryana, I. B. P. (2009). Meningkatkan Keterampilan Berpikir Tingkat Tinggi Melalui Pembelajaran. Singaraja: UNDIKSHA.

Ayan, Jordan E. (2002). Bengkel Kreativitas: 10 Cara Menemukan Ide-ide Pamungkas. Penerjemah Ibnu Setiawan. Aha!: 10 Ways to Free Your Creative Spirit and Find Your Great Ideas Bibliografi. 1997. Bandung. Kaifa

Boen. S. Oemarjati. (1990). Taksonomi Avertebrata (Pengantar praktek laboratorium). Jakarta: UI- Press.

Costa, A. L. (1985). Developing Minds A Resource Book for Teaching Thinking. Virginia: Association for Supervision and Curriculum Development.

Depdikbud. (1994). Jurnal Biologi. Jakarta: Depdikbud.

Depdiknas. (2003), Pedoman Khusus Pengembangan Silabus Mata Pelajaran Kimia, Jakarta, Depdiknas.

Depdiknas. (2002). Kurikulum Berbasis Kompetensi. Jakarta: Puskur, Balitbang Depdiknas

Duch, B.J, (1995), What is Problem Based Learning?, (on line) tersedia: http://www.udel.edu/pbl/curric/chem 103-prob.html (tanggal akses $4-01$ - 2016)
Ennis, (1996), Critical Thinking, New Jersey, Prentice Hall, Uper Saddle River

Filsaisme, Dennis K. (2008). Menguak Rahasia Berpikir Kritis Dan Kreatif. Jakarta: prestasi Pustaka.

Fraenkel, J.C. \& Wallen, N.E. (1992), How to Design and Evaluate Research in Education, New York, McGraw-Hill, Inc.

Hassoubah, Zaleha Izhab. (2007). Mengasah Pikiran Kreatif dan Kritis: Disertai Ilustrasi dan Latihan. Terjemahan Bambang Suryadi. Developing Creative \& Critical Thinking Skills: A Handbook for Students. 2002. Bandung: Nuansa

Hossoubah, Z. (2007). Develoving Creative and Critical Thinking Skills (terjemahan) . Bandung: Yayasan Nuansa Cendia.

Ibrahim, M., \& Mohamad N. (2000). Pengajaran Berdasarkan Masalah. Pusat Sains dan Matematika Sekolah. Surabaya: PPS UNESA

Liliasari. (2005), Membangun Keterampilan Berpikir Manusia Indonesia melalui Pendidikan sains (Pidato Pengukuhan Guru Besar Tetap IPA), Bandung, UPI.

Rusnadi, Ni Md. D. P. P. N. W. A. (2013). Penerapan Model Pembelajaran Kooperatif Tipe Team Games Tournament untuk Meningkatkan Kemampuan Berpikir Kritis dan Hasil Belajar Ipa. Mimbar Pgsd. Retrieved From Http://Ejournal.Undiksha.Ac.Id/ Index.Php/Jjpgsd/Article/View/881 